\title{
Saw Dust Ash Substitution for Cement Pastes-Part I
}

\author{
H. H. M. Darweesh ${ }^{1, ~ *, ~ M . ~ R . ~ A b o ~ E l-S u o u d ~}{ }^{2}$ \\ ${ }^{1}$ Refractories, Ceramics and Building Materials Department, National Research Centre, Dokki, Cairo, Egypt \\ ${ }^{2}$ Botany Department, National Research Centre, Dokki, Cairo, Egypt
}

Email address:

hassandarweesh2000@yahoo.com (H. H. M. Darweesh)

*Corresponding author

\section{To cite this article:}

H. H. M. Darweesh, M. R. Abo El-Suoud. Saw Dust Ash Substitution for Cement Pastes-Part I. American Journal of Applied Scientific Research. Vol. 3, No. 5, 2017, pp. 63-71. doi: 10.11648/j.ajasr.20170305.13

Received: October 18, 2016; Accepted: December 21, 2016; Published: November 28, 2017

\begin{abstract}
The saw dust (SD) is often used as a fuel which in turn leads to the environmental pollution. So, it must utilize this waste into useful applications to avoid what is known as "air pollution". In this study, the SD was converted to saw dust ash (SDA) by its firing at $500^{\circ} \mathrm{C}$. It is then used as a partial substitution for cement. The results showed that the water of consistency (WC), initial setting time (IST) and final setting time (FST) of the Portland cement pastes are decreased with the substitution of SDA due to the presence of Na-lignosulfonate. The bound water content (BW), bulk density (BD) and compressive strength (CS) increased with time of hydration up to 90 days, while the apparent porosity (AP) decreased. The BW, BD and CS of the cement pastes containing 5-15 wt. \% SDA are slightly higher than those of the blank (S0) at all hydration ages. The free lime content (FL) of the Portland cement pastes (S0) increased as the hydration progressed onward, whereas the cement pastes with SDA (S1-S5) only increased up to 3 days and then decreased. The FTIR spectra of the OPC without SDA showed that the free lime content increased as the hydration proceeded till 90 days, while that of the optimum cement mix containing $15 \mathrm{wt}$ \% SDA, the FL content increased only up to 3 days and then progressively decreased until nearly disappeared after 90 days.
\end{abstract}

Keywords: OPC, Saw Dust Ash, Hydration, Setting, Free Lime, Bulk Density, Apparent Porosity, Strength, IR

\section{Introduction}

It is well known that the prices of the conventional building materials are continuously increasing worldwide due to the over population. This had been led us to look for alternative local materials suitable to use in the construction process in order to obtain low-price buildings. Some of these local materials are Palm kernel shell [1], earthen plaster [2] and lateritic interlocking blocks [3].

The industrial by-products and/or agricultural residues often create some acute environmental problems as its disposal and health hazards. The construction industry is considered as the most popular that consumes many of these wastes as filler or as pozzolanic materials in cement or concrete [4]. So, it can add several technical advantages to the resulting cement or concrete structures. Also, larger amounts of these wastes could be substituted at the expense of cement after its conversion to ash [5]. Saw dust is an industrial by-product resulting from wood industry and it is characterizes by its very fine particles Saw dust is always coming from cutting, grinding, drilling, sanding and sawing wood at saw mills (Figure 1).
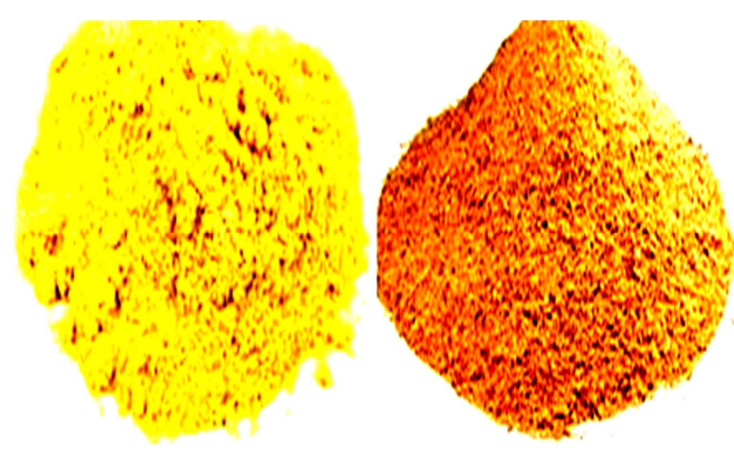

Figure 1. The saw or wood dust used in the current study.

The focus of the present study is to utilize this waste in the production of a useful product. It presents a hazard in manufacturing industries, especially in terms of its 
flammability. In wood industry, the disposal of SD is an increasing problem of high interest, where very huge amounts of SD are produced annually from sawmills. The wood mill often produces about 600 pounds of dry waste/1000 feet of wood. Some industrial byproducts have been studied for use as cementing materials such as Fly ash [6-8], Silica fume [7, 8], Pulverized fuel ash [9], Rice husk ash [10] and Corn cob ash [11-13].The influence of SDA as a partial substituting material at the expense of cement to produce a pozzolanic cement pastes and/or mortar [14], the properties of fresh concrete of self-compacting concrete (SCC) containing SDA [15] and the ash from agricultural residues as a cement substituting material were investigated [16]. Furthermore, the SDA was utilized as fine aggregates in concrete, i.e. it is possible to produce concrete containing SDA with similar properties to those of natural aggregates where the SDA content in concrete is limited to be from 1020 wt. \% [17]. Hence, adverse effects were resulted with saw dust ash content more than $20 \mathrm{wt}$ \%. The main objective of the current study is to explain the use of SDA as a partial substitution for Ordinary Portland cement (OPC) in cement pastes. It comprises the influence of the chemical composition of the SDA on the workability, water of consistency, setting times (initial and final), bulk density, apparent porosity and compressive strength of the hardened cement pastes. The results were confirmed by the infrared analysis (FTIR).

\section{Experimental and Methods}

\subsection{Raw Materials}

The raw materials are Ordinary Portland cement (OPC-1, $32.5 \mathrm{R})$ with a Blaine surface area of $3350 \mathrm{~cm}^{2} / \mathrm{g}$ was delivered from National Cement Company, El-Tibbin and the sawdust sample (SD) that received from local wood plants, Egypt. The sample of saw dust was sieved using $63 \mathrm{m \mu}$ sieve. The chemical analysis of the OPC and SDA specimens using the X-ray fluorescence (XRF) technique is shown in Table 1, while the mineralogical phase composition of the OPC sample as calculated from Bogue equations $[18,19]$ is given in Table 2.

Table 1. The oxide composition of the raw materials, wt.\%.

\begin{tabular}{|c|c|c|c|c|c|c|c|c|c|c|}
\hline Oxides Materials & L.O.I & $\mathrm{SiO}_{2}$ & $\mathbf{A l}_{2} \mathbf{O}_{3}$ & $\mathrm{Fe}_{2} \mathrm{O}_{3}$ & $\mathrm{CaO}$ & MgO & $\mathrm{Na}_{2} \mathrm{O}$ & $\mathbf{K}_{2} \mathrm{O}$ & $\mathbf{P}_{2} \mathbf{O}_{5}$ & $\mathrm{SO}_{3}$ \\
\hline OPC & 2.64 & 20.12 & 5.25 & 1.29 & 63.13 & 1.53 & 0.55 & 0.30 & 0.19 & 2.54 \\
\hline SDA & 0.84 & 66.17 & 4.35 & 2.36 & 10.06 & 4.41 & 0.08 & 0.12 & 0.46 & 0.42 \\
\hline
\end{tabular}

Table 2. Mineralogical composition of the OPC sample, mass $\%$.

\begin{tabular}{lllll}
\hline Phases Material & $\mathbf{C}_{3} \mathbf{S}$ & $\beta-\mathbf{C}_{2} \mathbf{S}$ & $\mathbf{C}_{3} \mathbf{A}$ & $\mathbf{C}_{4} \mathbf{A F}$ \\
\hline $\mathrm{OPC}$ & 46.81 & 28.43 & 5.90 & 12.56 \\
\hline
\end{tabular}

Sodium lignosulfonate superplastecize (Figure 2) was used because it is more active than conventional superplasticizers, where it contains several free carboxylic groups. This greatly improves cement dispersion. During mixing process, an electrostatic dispersion occurs and generates a steric hindrance which stabilizes the cement particles capacity to separate and disperse. This mechanism provides flow able concrete with greatly reduced water demand [18].

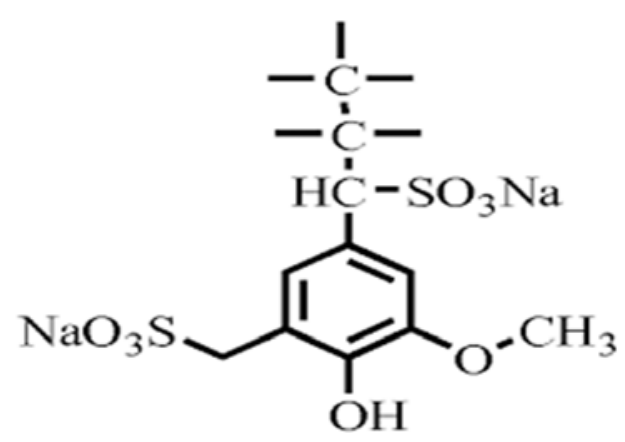

Figure 2. Chemical structure of sodium lignosulphonate.

\subsection{Physical Properties of Raw Materials}

The physical properties $[20,21]$ of the starting raw materials (OPC and SDA) in terms of basicity coefficient (bc), hydration modulus (hm), silicate modulus (sm), aluminate modulus (am) and lime modulus (Lm) are calculated from the following relations:

$$
\begin{aligned}
& \mathrm{bc}=\mathrm{C}+\mathrm{M} / \mathrm{S}+\mathrm{A} \\
& \mathrm{hm}=\mathrm{C} / \mathrm{S}+\mathrm{A} \\
& \mathrm{sm}=\mathrm{S} / \mathrm{A}+\mathrm{F} \\
& \mathrm{Am}=\mathrm{A} / \mathrm{F} \\
& \mathrm{Lm}=100 \mathrm{C} / 28 \mathrm{~S}+1.1 \mathrm{~A}+0.7 \mathrm{~F}
\end{aligned}
$$

\subsection{Preparation of Cement Pastes}

At first, the saw dust sample (SD) was processed and washed separately with running water for few minutes and then washed with distilled water, well dried under sun, burned at $500^{\circ} \mathrm{C}$ for $4 \mathrm{hrs}$ and then screened to pass through 200 mesh sieve $(63 \mu \mathrm{m})$ to obtain what is known as saw dust ash (SDA). Then, the OPC cement was substituted with 0,5 , 10, 15, 20 and 25 wt. \% of SDA as shown in Table 3 . The fineness of each cement mix and its density were determined (Table 3).

Table 3. Cement batches containing varying ratios of SDA, wt. \% as well as its determined fineness and density.

\begin{tabular}{lllll}
\hline Material Batches & OPC & SDA & Fineness, $\mathbf{c m}^{\mathbf{2}} \mathbf{g}$ & Density, $\mathbf{g} / \mathbf{c m}^{\mathbf{3}}$ \\
\hline S0 & 100 & 0 & 3350 & 2.3205 \\
S1 & 95 & 5 & 3764 & 2.1043 \\
S2 & 90 & 10 & 4100 & 1.9705 \\
S3 & 85 & 15 & 4445 & 1.9546 \\
S4 & 80 & 20 & 4670 & 1.9231 \\
S5 & 75 & 25 & 4825 & 1.8796 \\
\hline
\end{tabular}


The mixes are taken the symbols of $\mathrm{S}_{0}, \mathrm{~S}_{1}, \mathrm{~S}_{2}, \mathrm{~S}_{3}, \mathrm{~S}_{4}$ and $\mathrm{S}_{5}$. The mixes powder were first mixed with water to produce cement pastes and then moulded into one inch cubic stainless steel moulds $\left(2.5 \times 2.5 \times 2.5 \mathrm{~cm}^{3}\right)$, vibrated manually for two minutes and on a mechanical vibrator for another two minutes. The surfaces of pastes inside moulds were smoothed with a spatula and let to be were kept inside a humidity cabinet for $24 \mathrm{hrs}$ at $23 \pm 1^{\circ} \mathrm{C}$ and $100 \% \mathrm{R}$. H. In the following day, it demoulded and soon cured under water till the time of testing for bulk density, apparent porosity and compressive strength after 1, 3, 7, 28 and 90 days.

\subsection{Methods of Investigation}

The standard water of consistency (mixing water or w/c ratio) as well as setting times (initial and final) of the prepared cement pastes were directly determined using Vicat Apparatus [22, 23]. The water of consistency was determined from equation 6 :

$$
\mathrm{WC}, \%=\mathrm{H} / \mathrm{W} \times 100
$$

Where, WC is the water of consistency, $\mathrm{H}$ is the amount of water taken to produce a suitable paste and $\mathrm{W}$ is the weight of the dry cement ( $300 \mathrm{~g})$. The initial setting time (IST) is the time taken to reach the initial set, while the final setting time (FST) is the time taken to reach the final set of the paste. The bulk density and apparent porosity [16] of the hardened cement pastes were calculated from equations 7 and 8 , respectively:

$$
\begin{gathered}
\text { B.D, }\left(\mathrm{g} / \mathrm{cm}^{3}\right)=\mathrm{W}_{1} /\left(\mathrm{W}_{1}-\mathrm{W}_{2}\right) \times 1 \\
\text { A.P, } \%=\left(\mathrm{W}_{1}-\mathrm{W}_{3}\right) /\left(\mathrm{W}_{1}-\mathrm{W}_{2}\right) \times 100
\end{gathered}
$$

Where, B.D, A.P, $\mathrm{W}_{1}, \mathrm{~W}_{2}$ and $\mathrm{W}_{3}$ are the bulk density, apparent porosity, saturated, suspended and dry weights, respectively. The compressive strength [22] was measured by using a hydraulic testing machine of the Type LPM 600 M1 SEIDNER (Germany) having a full capacity of $600 \mathrm{KN}$ and the loading was applied perpendicular to the direction of the upper surface of the cubes and was determined from equation 9:

$$
\mathrm{Cs}=\mathrm{L}(\mathrm{KN}) / \mathrm{Sa}\left(\mathrm{cm}^{2}\right) \mathrm{KN} / \mathrm{m}^{2} \times 102\left(\mathrm{Kg} / \mathrm{cm}^{2}\right) / 10.2(\mathrm{MPa})
$$

Where, Cs: Compressive strength ( $\mathrm{MPa})$, L: load $(\mathrm{KN})$, $\mathrm{Sa}$ : surface area $\left(\mathrm{cm}^{2}\right)$.After measuring the mechanical strengths, the hydration of the cement pastes at each interval must be stopped using a mixture of methyl alcohol and diethylether. Then, the bound water content (BW) was determined on the basis of ignition loss $[18,21]$ from equation 10 :

$$
\mathrm{BW}, \%=\left(\mathrm{W}_{1}-\mathrm{W}_{2} / \mathrm{W}_{2}\right) \times 100
$$

Where, Wn, W1 and W2 are combined water content, weight of sample before and after ignition, respectively.

The free lime content of the hydrated samples pre-dried at $105^{\circ} \mathrm{C}$ for 24 hours was also determined [24-27]. About $0.5 \mathrm{~g}$ sample $+40 \mathrm{ml}$ ethylene glycol $\rightarrow$ heating to $20 \mathrm{~min}$. (without boiling). Add 1-2 drops of ph. ph. indicator to the filtrate and then titrate against freshly prepared $0.1 \mathrm{~N} \mathrm{HCl}$ till the pink color disappears. The $0.1 \mathrm{~N} \mathrm{HCl}$ was prepared using equation 11:

$$
\mathrm{V} 1=\mathrm{N} \times \mathrm{V} 2 \times 100 / \mathrm{D} \times \mathrm{P} \times 1000
$$

where, $\mathrm{V} 1$ is the volume of conc. $\mathrm{HCl}, \mathrm{V} 2$ is the volume required, $\mathrm{N}$ is the normality required, $\mathrm{W}$ is the equivalent weight, $\mathrm{D}$ is the density of Conc. $\mathrm{HCl}$ and $\mathrm{P}$ is the purity $\%$. Repeat heating and titration several times till the pink colour does not appear on heating. Calculate the free lime content from the following relation: $\mathrm{CaO} \%=(\mathrm{V} \times 0.0033 / 1) \times 100$, where $\mathrm{V}$ is the volume of $0.1 \mathrm{~N} \mathrm{HCl}$ taken on titration. The optimum cement mix was first selected and then was subjected to infrared analysis (IR) to confirm the obtained results. The IR spectra were carried out by Pye-Unicum SP1100 in the range of $4000-500 \mathrm{~cm}^{-1}$.

\section{Results and Discussion}

\subsection{Composition of Raw Materials}

The oxide compositions of the used raw materials (Portland cement and SDA) are recorded in Table 1. It shows that the cement is composed essentially of $\mathrm{CaO}$ $(63.13 \%)$ and $\mathrm{SiO}_{2}(20.12 \%)$ with 'small amount of $\mathrm{Fe}_{2} \mathrm{O}_{3}$ (1.29\%), a low ratio of $\mathrm{Al}_{2} \mathrm{O}_{3}(5.25 \%), \mathrm{MgO}(1.53 \%), \mathrm{SO}_{3}$ $(2.54 \%), \mathrm{Na}_{2} \mathrm{O}(0.55 \%), \mathrm{K}_{2} \mathrm{O}(0.30 \%)$ and free lime $(1.09 \%)$, while the loss on ignition is 2.64 . According to ASTM-Specification, C 618-12 a, 1978[28], the used cement is Type I-Ordinary Portland cement. Table 1 also shows that the saw dust ash (SDA) is composed of silica, $\mathrm{SiO}_{2}$ (66.17). So, it possesses a higher amount of alumina $\left(\mathrm{Al}_{2} \mathrm{O}_{3}\right)$, but a little amount of $\mathrm{Fe}_{2} \mathrm{O}_{3}$ (1.29). There are another constituents in variable amounts e.g. $\mathrm{MgO}(0.11)$, $\mathrm{Na}_{2} \mathrm{O}(0.03), \mathrm{K}_{2} \mathrm{O}$ (1.06), $\mathrm{Ti}_{2} \mathrm{O}(0.11)$ and $\mathrm{SO}_{3}(0.02)$. The loss on ignition of the saw dust ash sample is $0.84 \%$. When the total of $\mathrm{SiO}_{2}+\mathrm{Al}_{2} \mathrm{O}_{3}+\mathrm{Fe}_{2} \mathrm{O}_{3}$ is $\geq 70 \%$, the material could act as a pozzolanic material. On this basis, the total of $\mathrm{SiO}_{2}, \mathrm{Al}_{2} \mathrm{O}_{3}$ and $\mathrm{Fe}_{2} \mathrm{O}_{3}$ of the $\mathrm{SDA}$ is $89.5 \%$, i.e. $>70 \%$. So, the used SDA sample has a pozzolanic character. So, it can be used as a partial replacement for Ordinary Portland cement to produce pozzolanic cement [29].

\subsection{Relation Between Fineness and Density}

The determined values of both fineness and density of the OPC $\left(\mathrm{S}_{0}\right)$ and the various OPC/SDA cement mixes $\left(\mathrm{S}_{1}-\mathrm{S}_{5}\right)$ are shown in Table 3, whilst Figure 3 indicates the relation between them. It is clear that as the fineness of the cement batches increased due to the gradual incorporation of the very fine SDA, the density of the batches decreased. This may be due to that the SDA is very lighter in weight than OPC [2628]. This proves that the SDA sample is highly and more siliceous than the OPC sample. Moreover, the SDA sample has no hydraulic properties in nature if compared with OPC. The data shown in Table 1 illustrated that the SDA sample is 
adjusted to the ASTM-Specifications. So, it can be used as a mineral admixture for cement pastes, mortars and/or concretes [28-31].

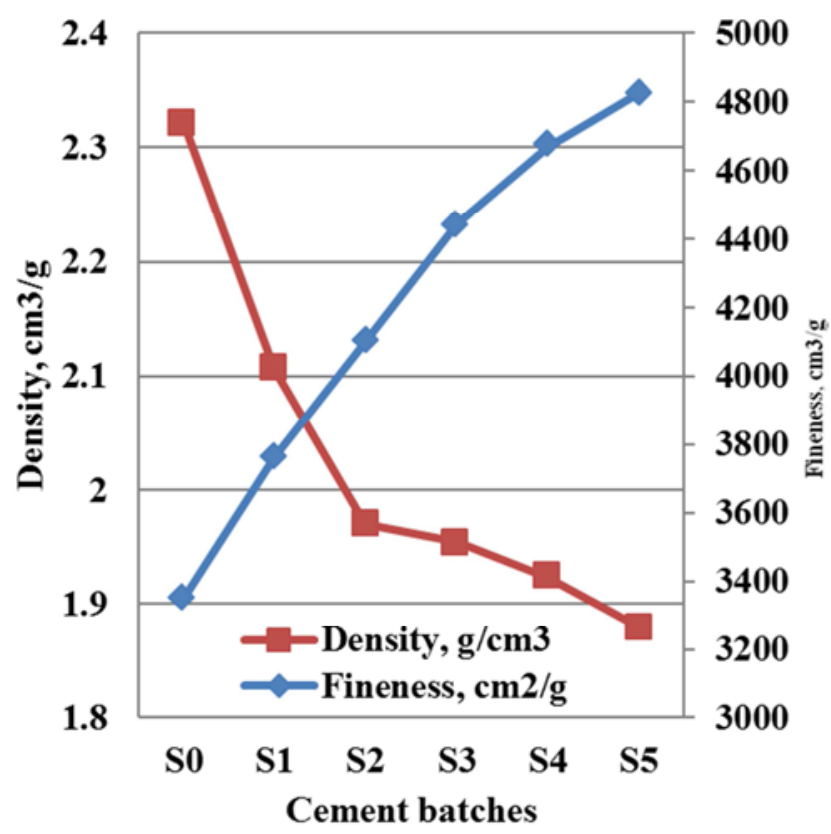

Figure 3. The relationship between the fineness of $O P C$ and $S D A$ raw materials and their densities.

\subsection{Relation Between bc, hm, sm, am and $\mathrm{Lm}$}

The relation between the physical properties of the OPC $\left(\mathrm{S}_{0}\right)$ and the various prepared cement mixes $\left(\mathrm{S}_{0}-\mathrm{S}_{5}\right)$ in terms of bc, hm, sm, am and Lm are graphically represented in Figure 4. It is clear that the OPC has a much higher values of $\mathrm{bc}, \mathrm{hm}$, am and Lm, whilst sm is much higher in SDA than in the OPC. This illustrates that SDA is siliceous and have no hydraulic characteristics. The data shown in Table 3 indicated that the SDA is fit to a large extent with the ASTM Standards to be used as a mineral admixture for cement pastes, mortars or even concretes [31-33].

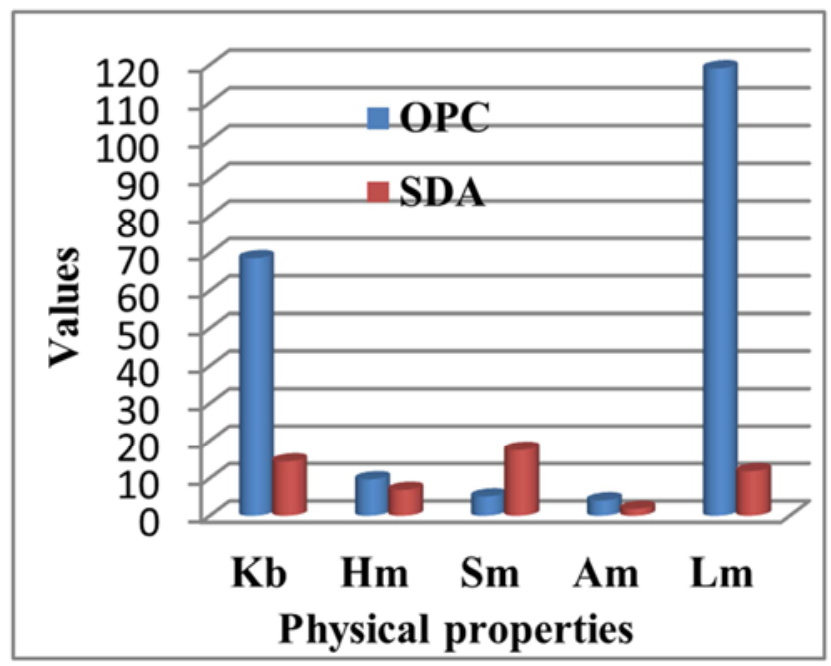

Figure 4. Physical properties of OPC and SDA samples.

\subsection{Water of Consistency and Setting Times}

The water of consistency and setting times of the OPC pastes $\left(\mathrm{S}_{0}\right)$ and the various SDA cement mixes $\left(\mathrm{S}_{1}-\mathrm{S}_{5}\right)$ are graphically represented in Figure 5 . The water of consistency slightly decreased as the SDA content increased. This is mainly attributed to the presence of the Sod. lignosulfonate admixture which is the main responsible factor for reducing the amount of mixing water [34-37]. Moreover, the higher fineness of the SDA $(63 \mu \mathrm{m})$ compared to that of the OPC $\left(3350 \mathrm{~cm}^{2} / \mathrm{g}\right)$ caused to decrease the amount of mixing water slightly $[18,34,36]$. Also, the setting times (initial and Final) also decreased gradually as the SDA content increased. This is primarily due to the high pozzolanic reactivity of the SDA with the evolved free lime coming from the hydration of the di- and tricalcium silicates phases of the cement [28, 33-38].

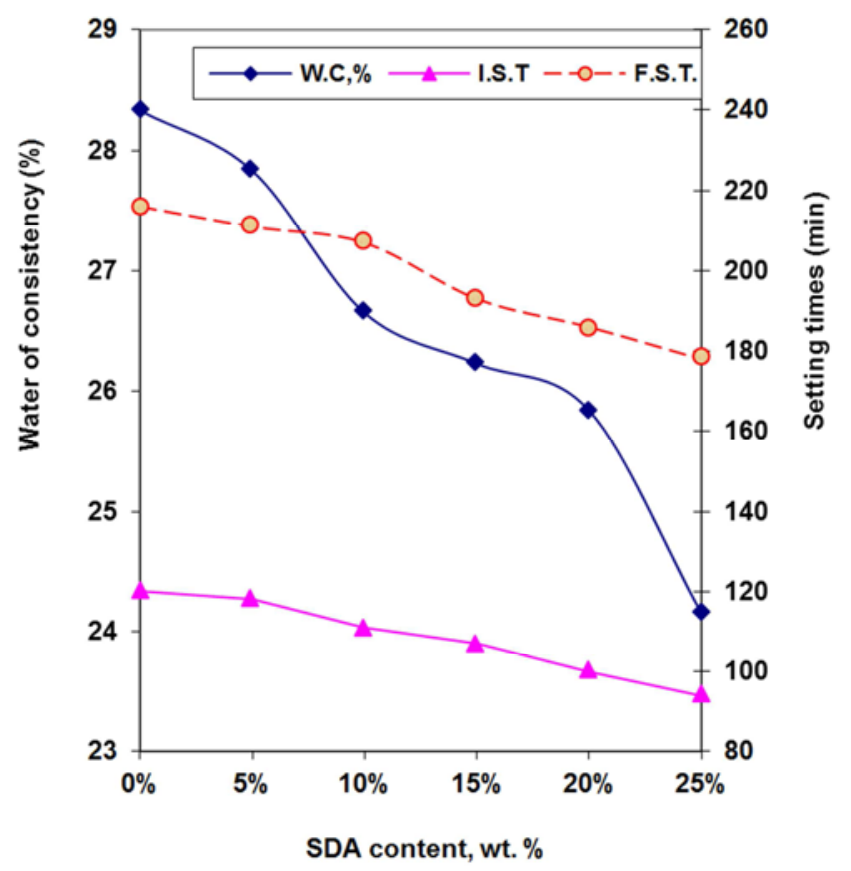

Figure 5. Water of consistency and setting times of the $O P C$ and the various $O P C / S D A$ cement pastes.

\subsection{Bound Water Content}

The bound water contents $(\mathrm{BW})$ of the control cement $\left(\mathrm{S}_{0}\right)$ and the various OPC/SDA cement pastes $\left(\mathrm{S}_{1}-\mathrm{S}_{5}\right)$ are plotted against to curing time up to 90 days in Figure 6. In general, the bound water content increased as the curing time proceeded up to 90 days. This is primarily due to the hydration of the cement phases. This is often leading to the formation of hydration products that characterizing with water molecules attained in the structure $[18,39]$. The bound water contents of the OPC/SDA cement mixes $\left(\mathrm{S}_{1}, \mathrm{~S}_{2}\right.$ and $\left.\mathrm{S}_{3}\right)$ at any hydration age are slightly higher than those of the control $\left(\mathrm{S}_{0}\right)$. This means that as the SDA content increased up to $15 \mathrm{wt} . \%$, the bound water content increased and seemed to be slightly higher than with the control $\left(\mathrm{S}_{0}\right)$. This is principally attributed to the pozzolanic reactivity of the SDA with the released $\mathrm{Ca}(\mathrm{OH})_{2}$ to form additional CSH $[18,26$, 
39-41]. If the SDA content is more than 15 wt. \%, the combined water content tended to decrease continuously. This is evidently due to the high deficiency of the main binding or hydrating material of OPC $[42,43]$.

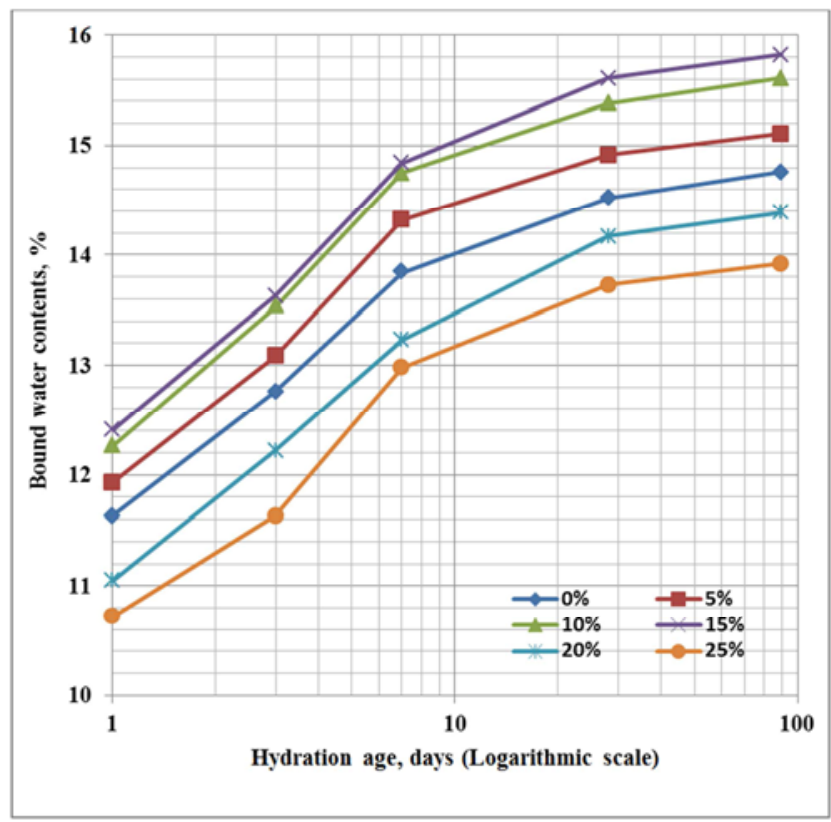

Figure 6. Chemically-combined water content of the OPC and the various OPC/ SDA cement pastes cured up to 90 days.

\subsection{Free Lime Content}

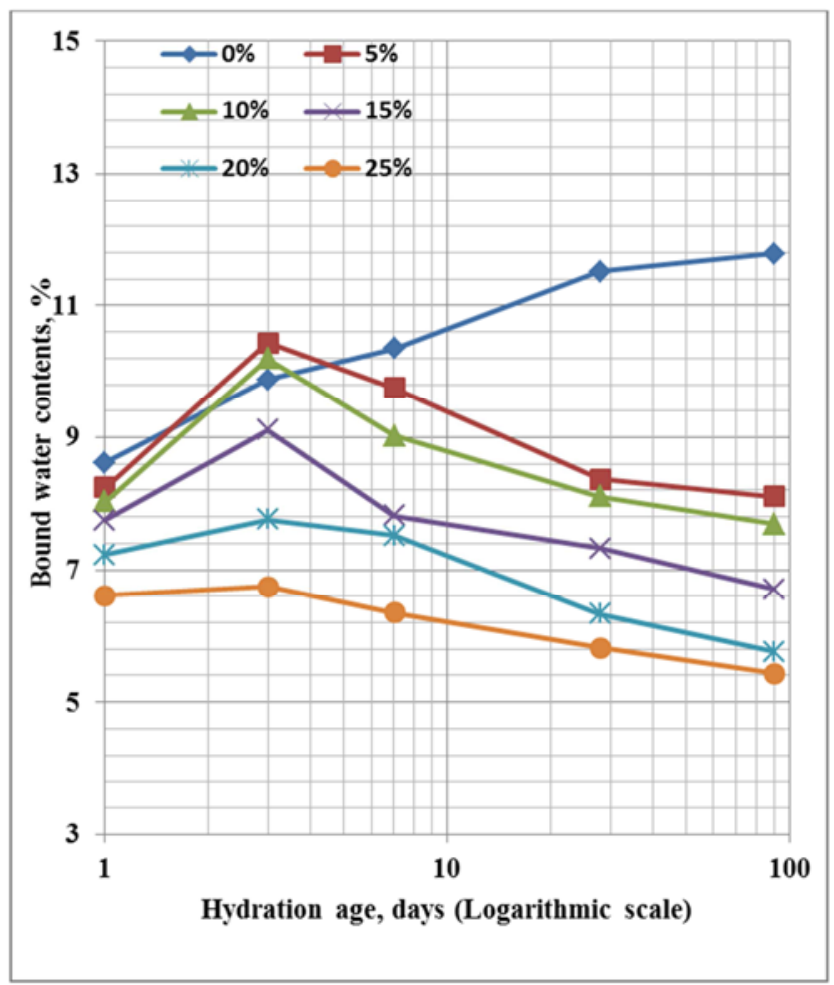

Figure 7. Free lime contents of the OPC and the various OPC / SDA cement pastes cured up to 90 days.

Figure 7 illustrates the free lime content of the OPC pastes
$\left(\mathrm{S}_{0}\right)$ and the various OPC/SDA cement mixes $\left(\mathrm{S}_{1}-\mathrm{S}_{5}\right)$. The free lime content of the hydrated OPC pastes increased gradually from the moment of the addition of water to the cement powder up to 90 days. This is due to the gradual and continuous hydration of $\mathrm{C}_{3} \mathrm{~S}$ and $\beta-\mathrm{C}_{2} \mathrm{~S}$ of cement phases to form the hydration products or $\mathrm{CSH}$ and/or CAH $[18,42]$. The free lime content of OPC/SDA cement mixes $\left(\mathrm{S}_{1}-\mathrm{S}_{5}\right)$ increased only up to 3 days of hydration and then decreased progressively. This means that the pozzolanic reactivity of SDA with $\mathrm{Ca}(\mathrm{OH})_{2}$ started after the third day of hydration. The cement mix containing $5 \mathrm{wt}$. \% SDA $\left(\mathrm{S}_{1}\right)$ exhibited the higher values of free lime content while that of $\mathrm{S}_{5}$ containing 25 wt. \% SDA recorded the lowest values. So, it could be concluded that the SDA has a high rate of pozzolanic activity.

\subsection{Bulk Density and Apparent Porosity}

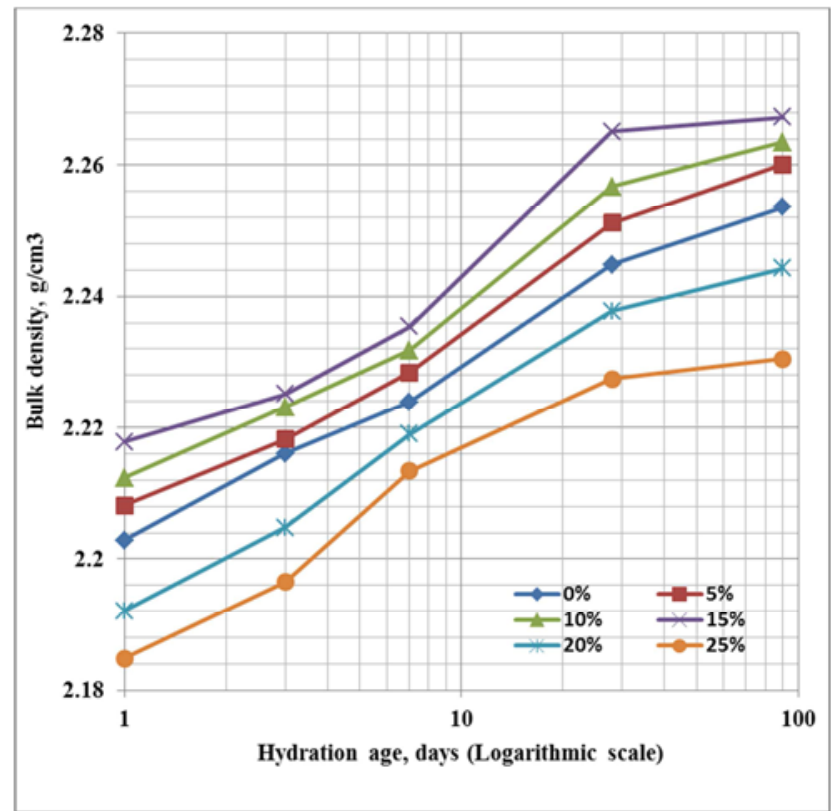

Figure 8. Bulk density of the OPC and the various OPC/ SDA cement pastes cured up to 90 days.

The results of bulk density and apparent porosity of the OPC $\left(\mathrm{S}_{0}\right)$ and the various OPC/SDA hardened cement pastes $\left(S_{1}-S_{5}\right)$ are plotted graphically against curing age up to 90 days of hydration in Figs. 8 and 9, respectively. Generally, the bulk density of the cement pastes $\mathrm{S}_{0}-\mathrm{S}_{5}$ increased stepwise up to 90 days while the apparent porosity decreased $[18,42]$. The bulk density of $\mathrm{S}_{1}-\mathrm{S}_{3}$ mixes containing 5-15 wt. \% SDA became slightly higher than that of the blank (S0), whilst the apparent porosity became lower. This may be due to the pozzolanic reactions between the constituents of the SDA and the released $\mathrm{Ca}(\mathrm{OH})_{2}$ from hydration process $[1-3,15,39]$. Moreover, they are very close to each other and also to the blank. With the SDA content $>15$ wt. $\%\left(\mathrm{~S}_{4}\right.$ and $\left.\mathrm{S}_{5}\right)$, the bulk density decreased largely and the apparent porosity increased comparing with those of the blank $\left(\mathrm{S}_{0}\right)$. The cement mix containing $15 \mathrm{wt}$ \% $\mathrm{SDA}\left(\mathrm{S}_{3}\right)$ exhibited the best bulk density and apparent porosity results. In 
contrast, the cement mix containing 25 wt. \% SDA $\left(\mathrm{S}_{5}\right)$ showed the lowest values. Accordingly, with 15 wt. \% SDA content, the cement mix is the optimum one.

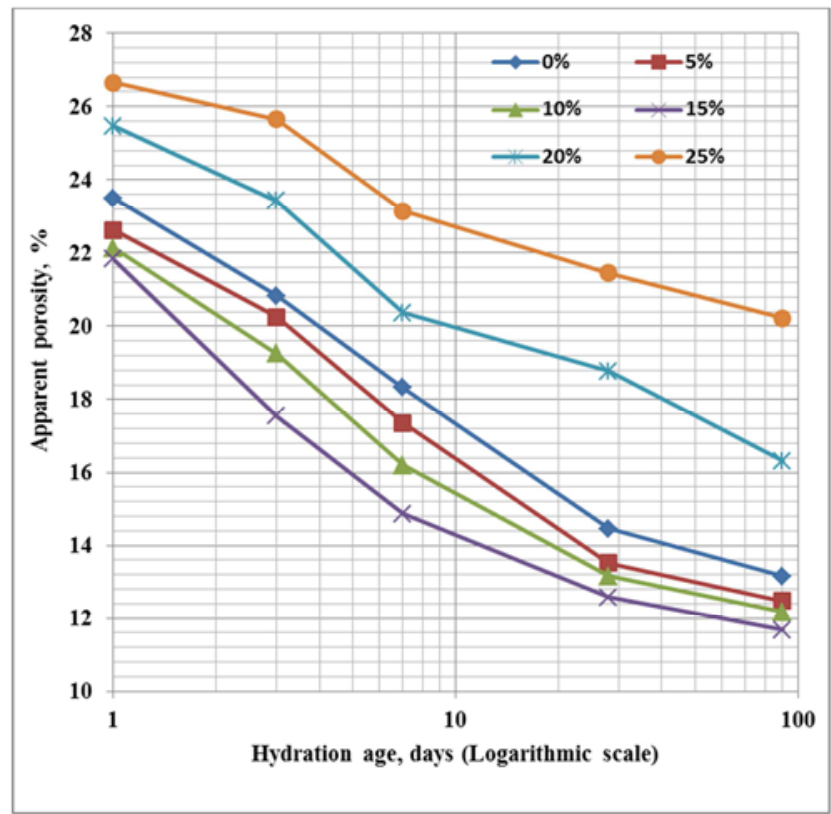

Figure 9. Apparent porosity of the $O P C$ and the various $O P C / S D A$ cement pastes cured up to 90 days.

\subsection{Compressive Strength}

The compressive strength is represented against curing time up to 90 days in Figure 10. The compressive strength of the OPC pastes $\left(\mathrm{S}_{0}\right)$ increased as the curing time proceeded up to 90 days. This is mainly due to the progressing of hydration process with time of hydration $[18,19,26,42]$. The compressive strength of the various blended cement pastes $\left(\mathrm{S}_{1}-\mathrm{S}_{5}\right)$ displayed the same trend as occurred with the blank (S0). Furthermore, the compressive strength of $\mathrm{S}_{1}-\mathrm{S}_{3}$ mixes containing 5-15 wt. \% SDA appeared to be slightly higher than those of the blank at all hydration stages. It is essentially contributed to the high pozzolanic reactivity of SDA with the released free lime from the hydration process of the OPC phases [43-45], in addition to the high dispersion of mix ingredients due to the presence of Sod. lignosulfonate admixture in the mixing water and the high compaction of samples during molding[37].With cement blends $\mathrm{S}_{4}$ and $\mathrm{S}_{5}$ containing 20 and $25 \mathrm{wt} \% \mathrm{SDA}$, the compressive strength highly decreased if compared with those of $\mathrm{S}_{1}-\mathrm{S}_{3}$ or even with the blank. This may be due to the decrease of hydration rate resulting from the loss of a higher quantity of the main binding or cementiteous material responsible for the hydration process which in turn responsible for the improving of mechanical properties as a whole, i.e. the presence of a higher quantity of SDA will hinder the hydration process to a large extent in spite of its beneficially as a pozzolanic material. This reflected negatively on the compressive strength [43-46]. Therefore, the big quantities of SDA must be avoided when added to
OPC. As a result, the cement blend containing $15 \mathrm{wt} \%$ is considered the optimum one. It is well known that the main phases of the OPC are $C_{3} S, \beta-C_{2} S, C_{3} A$ and $C_{4} A F$. When the afore phases are being in contact with water, they start to hydrate $[18,19,33,39,42]$ as shown in equations 12-15.

$$
\begin{array}{r}
\mathrm{C}_{3} \mathrm{~S}+\mathrm{H}_{6} \rightarrow \mathrm{C}_{3} \mathrm{~S}_{2} \mathrm{H}_{3}+3 \mathrm{CH} \\
\beta-\mathrm{C} 2 \mathrm{~S}+\mathrm{H} 4 \rightarrow \mathrm{C}_{3} \mathrm{~S}_{2} \mathrm{H}_{3}+\mathrm{CH} \\
\mathrm{C}_{3} \mathrm{~A}+\mathrm{CS}+\mathrm{H}_{12} \rightarrow \mathrm{C}_{3} \mathrm{~A} .3 \mathrm{CS} . \mathrm{H}_{32} \\
\mathrm{C}_{4} \mathrm{AF}+2 \mathrm{CH}+\mathrm{H}_{10} \rightarrow \mathrm{C}_{6} \mathrm{AFH}_{12}
\end{array}
$$

The constituents of SDA can react of gypsum $\left(\mathrm{CaSO}_{4} \cdot 2 \mathrm{H}_{2} \mathrm{O}\right)$ in the presence of water to form ettringite $\left(\mathrm{C}_{3} \mathrm{~A} .3 \mathrm{CS}^{-} . \mathrm{H}_{32}\right)$ and $\mathrm{CSH}$. Furthermore, they can react with a part of the free lime coming from the hydration ofthe OPC phases $\left(\mathrm{C}_{3} \mathrm{~S}\right.$ and $\left.\beta-\mathrm{C}_{2} \mathrm{~S}\right)$ to form additional ettringite and $\mathrm{CSH}$ or $\mathrm{CAH}[4,14,33]$ as in equations 16 and 17 :

$$
\begin{aligned}
& \mathrm{C}_{16} \mathrm{~S}_{13} \mathrm{~A}+\mathrm{CS}+\mathrm{H} \rightarrow 3 \mathrm{C}_{3} \mathrm{~A} .3 \mathrm{CS} . \mathrm{H}_{32}+13 \mathrm{CS} . \mathrm{Hx} \\
& \mathrm{C}_{6} \mathrm{~S}_{5} \mathrm{~A}+2 \mathrm{CH}+\mathrm{H} \rightarrow 3 \mathrm{C}_{3} \mathrm{~A} .3 \mathrm{CS} . \mathrm{H}_{32}+5 \mathrm{CSHx}
\end{aligned}
$$

The essential constituents of SDA are $\mathrm{SiO}_{2}$ and $\mathrm{Al}_{2} \mathrm{O}_{3}$. These constituents can react with a higher part of the released $\mathrm{Ca}(\mathrm{OH})_{2}$ during the hydration process to form cubic crystals of hydrogarnet $\left(\mathrm{C}_{3} \mathrm{~A} . \mathrm{S}_{2} . \mathrm{Hn}\right)[18,33,42,46]$ as shown in equation 18:

$$
\mathrm{A}+\mathrm{CH}+\mathrm{H} \rightarrow \mathrm{C}_{3} \mathrm{AS}_{2} \cdot \mathrm{Hn}
$$

The existence of these new phases is mainly responsible for the improving and enhancing of mechanical properties of the cement pastes at al curing ages of hydration up to 90 days.

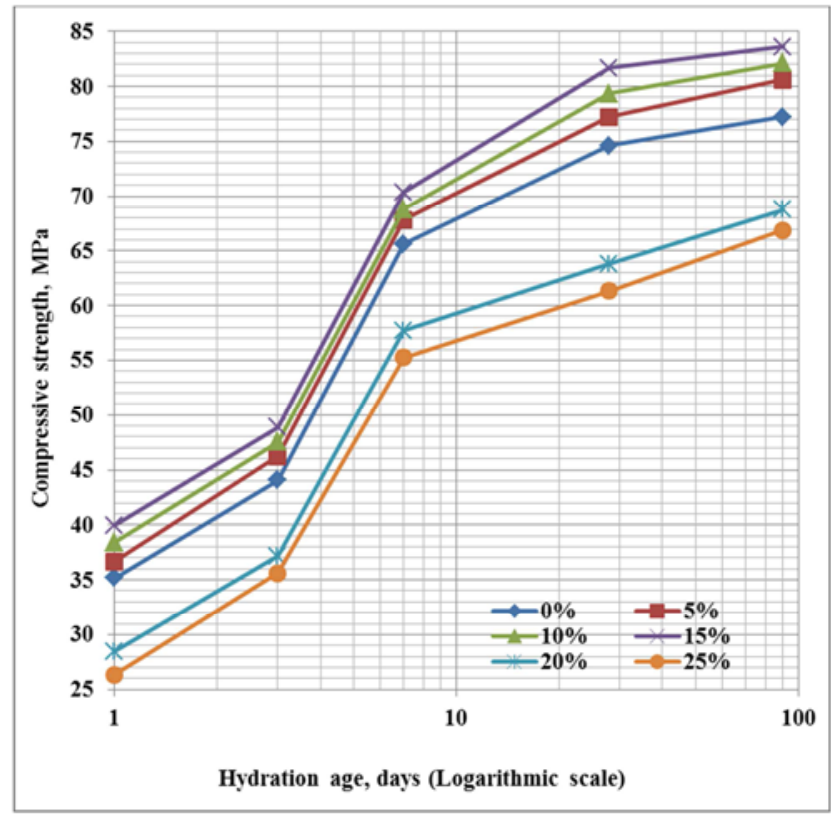

Figure 10. Compressive strength of the $O P C$ and the various $O P C / S D A$ cement pastes cured up to 90 days. 


\subsection{Infrared Analysis}

Figures. 11 and 12 demonstrate the infrared analysis of the blank $\left(\mathrm{S}_{0}\right)$ hydrated up to 90 days and the optimum cement mix $\left(\mathrm{S}_{3}\right)$ containing $15 \mathrm{wt}$ \% SDA hydrated up to 28 days. The sharp absorption band at $3653-3642 \mathrm{~cm}^{-1}$ is due to the free $\mathrm{OH}^{-}$group coordinated to $\mathrm{Ca}^{+2}$, i.e. free lime. As it is clear, it increased as the hydration proceeded (Figure 11), but it decreased gradually with curing time until disappeared at 28 days. This means that the addition of SDA to the cement mix increased the rate of pozzolanic reactivity of the SDA with the evolved $\mathrm{Ca}(\mathrm{OH})_{2}$. The intensity of the broad absorption band at $3455-3430 \mathrm{~cm}^{-1}$, is contributed to the $\mathrm{OH}^{-}$ group attached to $\mathrm{H}^{+}$bond which related to the symmetrical stretching frequency of water. This band increased in presence of SDA due to the formation of hydration products (CSH and/or CAH). The two absorption bands at 1645-1640 $\mathrm{cm}^{-1}$ and $1432-1423 \mathrm{~cm}^{-1}$ are due to the main silicate band involving Si-O stretching vibration bands of $\mathrm{CSH}$, while the band at $1124-1113 \mathrm{~cm}^{-1}$ may be due to CAH. The intensities of the two absorption bands at 993-984and $875 \mathrm{~cm}^{-1}$ characterizing $\mathrm{CO}_{3}^{-2}$ and $\mathrm{SO}_{4}^{-2}$, respectively are irregular due to the degree of carbonation or sulfonation of $\mathrm{CSH}$ or $\mathrm{CAH}$, where the vibrations of $\mathrm{CO}_{3}{ }^{-2}$ are smaller than those of $\mathrm{SO}_{4}{ }^{-2}$. The intensity of the absorption bands of $\mathrm{Si}-\mathrm{O}, \mathrm{CAH}, \mathrm{CO}_{3}{ }^{-2}$ and $\mathrm{SO}_{4}^{-2}$ are slightly higher with blends containing SDA than with the blank $\left(\mathrm{S}_{0}\right)$.

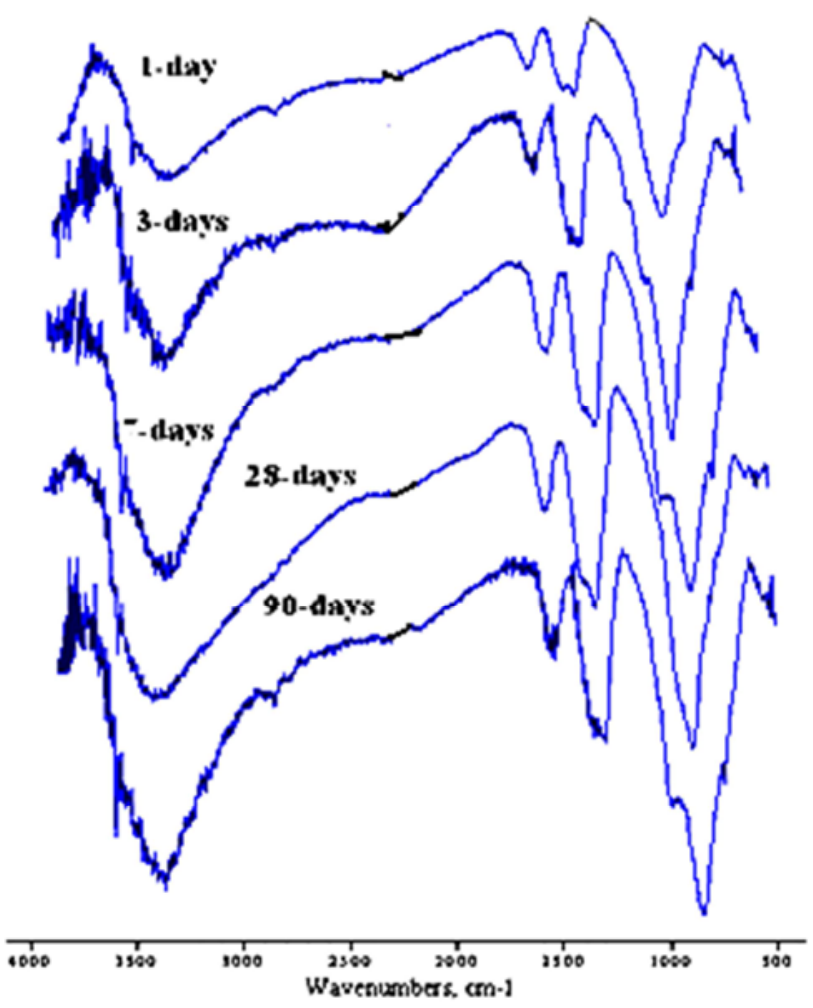

Figure 11. The FT-IR spectra of the OPC cement paste (SO) hydrated up to 90 days.

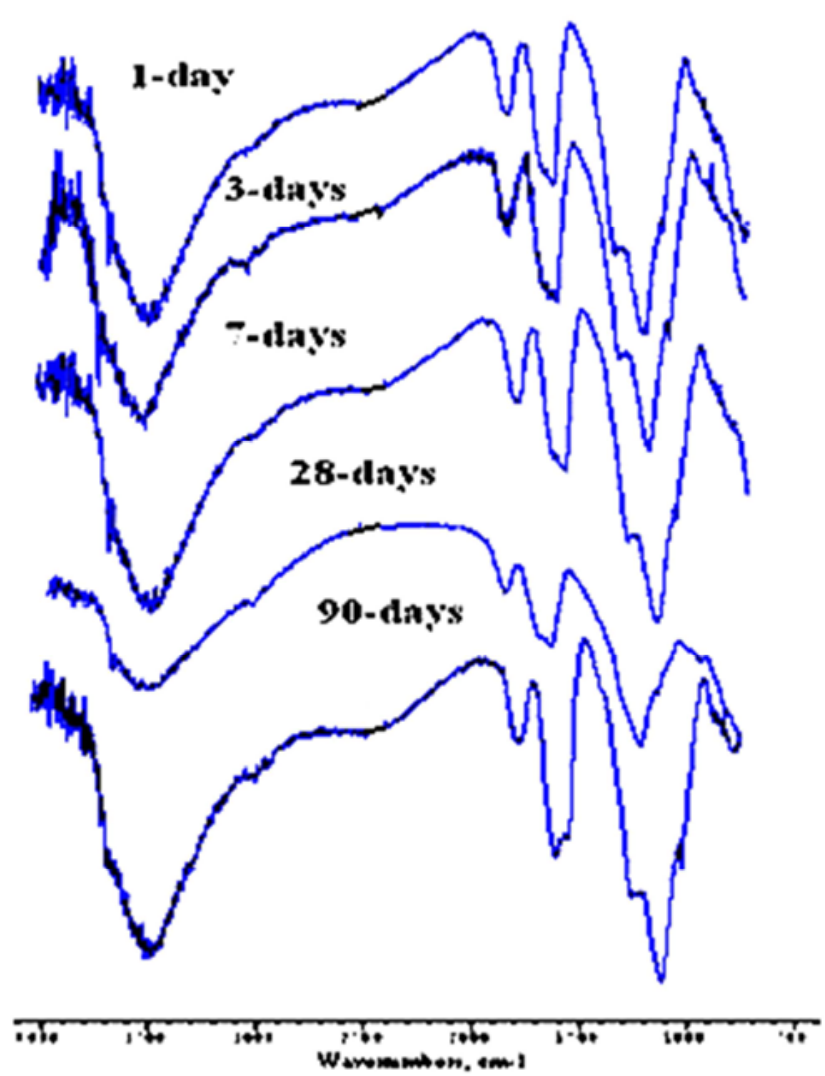

Figure 12. The FT-IR spectra of the optimum cement paste (S3) containing $15 \mathrm{wt} \%$ SDA at 28 days of hydration.

\section{Conclusions}

The water of consistency and setting times of the OPC cement pastes stepwise decreased with the increase of SDA content in the presence of sod. lignosulfonate superplasticizer in mixing water during moulding. The bound water content, bulk density and compressive strength increased gradually with curing time up to 90 days, while the apparent porosity decreased. The chemically-combined water content, bulk density and compressive strength of the cement pastes containing 5-15 wt. \% SDA $\left(\mathrm{S}_{1}-\mathrm{S}_{3}\right)$ are slightly higher than those of the OPC pastes $\left(\mathrm{S}_{0}\right)$ at all curing ages of hydration. The free lime content of the OPC $\left(\mathrm{S}_{0}\right)$ increased as the curing time progressed to 90 days, while those of the cement pastes containing SDA only increased up to 3 days and then decreased onward. The FTIR spectra of the blank $\left(\mathrm{S}_{0}\right)$ increased onward up to 90 days of hydration, whereas that of the optimum cement $\operatorname{mix}\left(\mathrm{S}_{3}\right)$ containing $15 \mathrm{wt}$. \% SDA, the intensity of the peaks characterizing the free lime at $3653-3642 \mathrm{~cm}^{-1}$ increased up to 3 days of hydration and then diminished with curing time till completely disappeared after 90 days of hydration. Accordingly, it could be recommended that this study could apply successfully in the countries containing thick trees or forests from which the saw dust could be obtained through processing. 


\section{References}

[1] Raheem, A. A.; Nwakanma, E. O. and Ogunleye, K. O., "Engineering Properties of Concrete with Palm Kernel Shell as Fine and Coarse Aggregates", USEP, Journal of Research Information in Civil Engineering (RICE), Vol. 5 No.1, 2008, 58-70.

[2] Svoboda, P. and Prochazka, M., "Outdoor earthen plasters", Organization, Technology and Management in Construction: an International Journal, Vol. 4 No. 1, 2012, 420-423.

[3] Raheem, A. A.; Falola, O. O. and Adeyeye, K. J. "Production and Testing of Lateritic Interlocking Blocks", Journal of Construction in Developing Countries, Malaysia, Vol.17 No.1, 2012, 35-50.

[4] Antiohos, S.; Maganari, K.; Tsimas, S. (2005), "Evaluation of blends of high and low calcium fly ashes for use as supplementary cementing materials", Cement \& Concrete Composites, Vol. 27, 2005, 349-356.

[5] Hossain, K. M. A. (2003), "Blended Cement using Volcanic Ash and Pumice", Cem. Concr. Res., Vol. 33, 2003, 16011605.

[6] Siddique, R. (2004), "Performance characteristics of highvolume Class F fly ash concrete", Cem. Concr. Res., Vol. 34 No.3, 2004, 487-493.

[7] Wang, S.; Miller, A.; Llamazos, E.; Fonseca, F. and Baxter, L. (2008), "Biomass fly ash in concrete: Mixture proportioning and mechanical properties", Fuel, Vol. 87, pp. 365-371.

[8] Wang, S. and Baxter, L. "Comprehensive study of biomass fly ash in concrete: Strength, microscopy, kinetics and durability", Fuel Processing Technology, Vol. 88, 2007, 11651170 .

[9] Balendran, R. V. and Martin-Buades, W. H. (2000), “The influence of high temperature curing on the compressive, tensile and flexural strength of pulverized fuel ash concrete", Building and Environment, Vol. 35 No.5, pp.415-423.

[10] Waswa-Sabuni, B.; Syagga, P. M.; Dulo, S. O. and Kamau, G, N. (2002), "Rice Husk Ash Cement - An Alternative Pozzolana Cement for Kenyan Building Industry", Journal of Civil Engineering, JKUAT, Vol. 8, pp. 13-26.

[11] Adesanya, D. A. and Raheem, A. A. (2009), "A study of the workability and compressive strength characteristics of corn cob ash blended cement concrete", Construction and Building Materials, Vol. 23, 2009, 311-317.

[12] Adesanya, D. A. and Raheem, A. A. (2009), "Development of corn cob ash blended cement", Construction and Building Materials; Vol. 23, 2009, 347 - 352.

[13] Raheem, A. A.; Oyebisi, S. O.; Akintayo, S. O. and Oyeniran, M. I. (2010), "Effects of admixtures on the properties of corn cob ash cement concrete", Leonardo Electronic Journal of Practices and Technologies, Vol. 16, 2010, 13 - 20.

[14] Cheah, C. B. and Ramli, M. "The implementation of wood waste ash as a partial cement replacement material in the production of structural grade concrete and mortar: an overview Review Article, Resources, Conservation and Recycling, Vol. 55, Issue 1, 2011, 669-685.
[15] Elinwa, A. U.; Ejeh, S. P. and Mamuda, A. M. (2008) "Assessing of the fresh concrete properties of self-compacting concrete containing sawdust ash, Construction and Building Materials, Vol. 22 Issue 6, 2008, 1178-1182.

[16] Elinwa. A. U. and Mahmoodb, Y. A. (2002) "Ash fron timber waste as cement replacement material, Cement and Concrete Composites, Vol. 24, Issue 2, 2002, 219-222.

[17] Mageswari, M. and Vidivelli, B. "The use of saw dust ash as fine aggregate replacement in concrete", Journal of Environmental Research and Development, Vol. 3 No. 3, January-March 2009, 720-726.

[18] Hewlett, P. C. "Lea's Chemistry of Cement and Concrete"; $4^{\text {th }}$ Edn.; John Wiley \& Sons Inc, New York, 1998.

[19] Neville, A. M. "Properties of concrete". $4^{\text {th }}$ edn. Essex (UK): Longman, 1995.

[20] Kersener, Z.; Darweesh, H. H. M. and Routil, L. "Mortar composites from waste materials" J. Cem. Hormigon, Spain, Vol. 2, No. 943, 2011, 12-19.

[21] Keršner, Z.; Darweesh, H. H. M. and Řoutil,L. "Pastas de cemento con unelev adocontenido de escorias activadasa lcalinamente con silicato de sodioy`water glass", Revista Tecnica CEMENTO HORMIGON, ISSN: 0008-8919, No. 945, 2011, 16-24.

[22] ASTM -Standards "Standard Test Method for Normal water of Consistency of Hydraulic Cement", C187-86, 1993, 148150 .

[23] ASTM - Standards "Standard Test Method for Setting Time of Hydraulic Cement”, C191-92, 1993, 866-868.

[24] ASTM-Standards "Standard Test Method for Compressive Strength of Dimension Stone", C170-90, 1993, 828-830.

[25] Darweesh, H. H. and Awad, H. M. "Effect of the calcination temperature and calcined clay substitution on the properties of Portland cement pastes", iiCl'industria italiana del Cemento, 844, 2008, 486-401.

[26] El-Didamony, H.; Darweesh, H. H. M and Mostafa, R. A. "Characteristics of pozzolanic cement pastes Part I: Physicomechanical properties" Sil. Ind. (Cer. Sci. \&Techn.), Belgium, 73, Nr. 11-12, 2008, 193-200.

[27] Darweesh, H. H. M. "Utilization of Perlite Rock in Blended Cement-Part I: Physicomechanical Properties", J. Chemical and Materials Sciences, (DRCMS), ISSN 2354-4163, Vol. 2, No. 1, 2014, 1-12.

[28] Darweesh, H. H. M. and Abo El-Suoud, M. R. "Setting, hardening and mechanical properties of some cement / agrowaste composites - Part I", Amer. J. Mining and Metallurgy, Vol. 2, No. 2, 2014, 32-40.

[29] ASTM-Standards, "Standard Specification for Coal Fly Ash and Raw or Calcined Natural Pozzolan for Use in Concrete", C 618-12 a, 1978.

[30] Rukzon, S. and Chindaprasirt, P. "Strength of ternary blended cement mortar containing Portland cement, rice husk ash and fly ash”, J. Eng. Inst. Thailand, 17, 2006, 33-37.

[31] Raheem, A. A.; Olasunkanmi, B. S. and Folorunso, C. S. "Saw Dust Ash as Partial Replacement for Cement in Concrete", Intern. Journ. of Organization Technology and Management in Construction, 4, 2, 2012, 474-479. 
[32] Metha, P. K. "Proc. work shop on rice husk ash cement", Peshawar, Pakistan. Bangalore, India: Reg. 1 Cent. Techn. Trans., 1979, 113-122.

[33] Darweesh, H. H. M. "Setting, hardening and strength properties of cement pastes with zeolite alone or in combination with slag" InterCeram (Intern. Cer. Review), Germany, Vol. 1, 2012, 52-57.

[34] Ramachandran, V. S.; Feldman, R. F.; "Concrete Admixtures Handbook, Properties, Science and Technology", $2^{\text {nd }}$ Edn.; Noyes Publications: New Jersey, 1995.

[35] Aiad, I. "Influence of time addition of superplasticizers on the rheological properties of fresh cement pastes", Cem. Concr. Res., 33, 8, 2003, 1229-1234.

[36] Darweesh, H. H. M. "Utilization of Ca-lignosulphonate prepared from black liquor waste as a cement superplasticizer", J. Chemistry and Materials Research, Vol., 1, No. 2, 2014, 28-34.

[37] Darweesh, H. H. M. "Black liquor waste as a cement admixture or Cement and/or concrete Admixtures", Chapter 6 of Book entitled "Biopolymers and Biotech. Admixtures for Eco Efficient Construction Materials" by F. Pacheco-Torgal, V. Ivanov, N. Karak and H. Jonkers, 2015, 99-130.

[38] Abdel-Kader, A. H. and Darweesh, H. H. M. "Setting and hardening of Agro/cement composites", BioResources, 4 (1), 2010, 43-54.

[39] Darweesh, H. H. M. "Effect of the combination of some pozzolanic wastes on the properties of Portland cement pastes" iiCL'industria italiana del Cemento, Italy, 808, 2005, 298-311.

[40] Elinwa, A. U. and Ejeh, S. P. (2004), "Effects of the incorporation of sawdust waste incineration fly ash in cement pastes and mortars", Journal of Asian Architecture and Building Engineering, Vol. 3 No.1, pp.1-7.

[41] Hague, M. N. and Kayali, O. (1998), "Properties of HighStrength Concrete using a Fine Fly Ash", Cement and Concrete Research, Vol. 28 No.10, pp. 1445-1452.

[42] Echart, A.; Ludwig,H. M. and Stark, J. "Hydration of the four main Portland cement clinker phases", Zement-Kalk-Gips, 28, 8, 1995, 443-452.

[43] Onwuka, D. O.; Anyaogu, L. and Chijioke, C. and Okoye, P. C. "Prediction and Optimization of Compressive Strength of Sawdust Ash-Cement Concrete Using Scheffe's Simpex Design”, Intern. Journ.of Sci. and Res. Pub., ISSN 2250-3153, $3,5,2013,1-9$.

[44] Darweesh, H. H. M. and Abo-El-Suoud, M. R. "Quaternary cement composites from industrial byproducts to avoid the environmental pollution", J. EC-Chemistry, 2, 1, 2015, 78-91.

[45] Elinwa, A. U. and Abdulkadir, S. (2011) "Characterizing Sawdust ash for Use as an inhibitor for Reinforcement Corrosion" New Clues in Science. 1-10.

[46] Raheem, A. A.; Olasunkanmi, B. S. and Folorunso, C. S. "Saw Dust Ash as Partial Replacement for Cement in Concrete", Technology and management in construction, 4, 2, 2012, 474-480. 